الدورية العلمية لكلية الفنون الجميلة - جامعة الإسكندرية

SJFA

Scientific Journal of the Faculty of Fine Arts Alexandria University

Print ISSN: 2356-8038

Online ISSN: 2535-227x

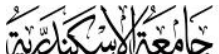

ALEXANDRIA

U N I V ER SITY

\title{
An Evaluative Approach for the development of Historical Public Squares
}

\author{
Nour Mazroua ${ }^{1}$
}

\begin{abstract}
Urban public squares, within the context of public spaces, are essential components of cities because they provide spaces for social interaction. They help sustain public experience through gathering, lingering and wandering through, and engaging together in various human activities and can make significant contributions to communities' development. In the last three decades, the concept of public space has been redefined within the context of urban space development and new places like shopping malls, parking lots, heavy traffic roads, which made traditional public spaces such as squares, plazas, and neighborhood streets in many instances become disregarded spaces. This paper aims to discover new approaches to make a successful transformation for the disregarded public squares through identifying public squares and their significance for the city and investigates the relationship between preference and perceived attributes through a comparative analysis of users" and decision-makers" perceptions by presenting critically of published related papers through summary, classification, and comparison of prior research studies, reviews of literature, and theoretical articles. Then it determines the framework that could be carried out to revive the disregarded public squares through analyzing successful examples that developed disregarded public squares to offer a great public experience.
\end{abstract}

KEYWORDS: Reinvigorating Public Squares, Urban Dis-Regardless, Disregarded Squares, Public Experience.

\section{Introduction}

\subsection{The problem definition:}

many cities have public squares which are disregarded and use-less even if they are in good condition and a very central and accessible location.

\subsection{The aim and objectives:}

This paper aims to explore new approaches to rediscover these disregarded public squares and enhance public life experience to make people love being there and stay, and this can be achieved through certain objectives:

\footnotetext{
${ }^{1}$ A postgraduate student, Department of Architecture and Environmental, Design Arab Academy for Science and Technology. nourmazrouaa@gmail.com
} 
1. To identify public squares and their significance for cities.

2. Investigate the relationship between preference and perceived attributes,

3. Determine assessment criteria to be applied on public squares.

\subsection{Methodology:}

To satisfy the objectives of the paper:

1. Analyze critically published related papers through summary, classification, and comparison of prior research studies, reviews of literature, and theoretical articles.

2. Analyze example that transformed disregarded public square into a high destination to get clear design guideline.

3. Apply the assessment criteria that have been concluded from the literature review on the example to check out this square's condition before and after the transformation.

\section{Literature Review}

\subsection{Urban square significance:}

Public squares are the first form of how humans used the urban open spaces without a doubt. The public square, as one of the unique urban structure elements. It has a valuable historical background that goes 6000 years back since the first city formation when they were at important intersections. The earliest example of public squares is the Greek' Agora'. Like any city component, it has been changed from time to time according to the city planning development. Although it has been changed from agora to roman forum until it became the public square that is known today, the public square is the open space that is surrounded by architectural elements to be considered as the focal point of the urban context that provide a chance for social interaction, cultural and economic activities.

Public squares' uses are multiple, and all have a perfect impact on the city image, comfort, economy, and user well-being. And each public square can be used for a specific purpose like social, cultural, political, commercial, recreational, or it can be used as a multi-function public space as its initial use since it exists.

Through time public square's pattern use has changed as they became more crowded with people and cars. And with the appearance of shopping centers, people have begun to spend their time indoors rather than in open public spaces. As a result, the urban squares have lost their value and importance in many countries. However, by the mid of 20th century, the debate of the importance and value of the public squares has been reactivated after several studies dealing with human well-being and urban development was referring to the importance of public spaces in general and public squares specifically. As a result, some pioneers' urbanists paid attention to public square design principles and guidelines such as J. Jacob, w. Whyte, Lynch, Cullen, and others.

\section{2.urban square design:}

A number of these studies dealing with the design of urban squares through a physical approach (Cullen, 1961), while others have a psychological approach (Alexander, 1979; Lynch, 
1960). Also, some studies provide an approach combining both physical and psychological approaches like (Jacobs, 1960; Whyte, 1980; Gehl, 1989).

\subsubsection{Physical design attributes:}

The square has three confining elements: the surrounding structures row, the floor expansion, and the sky above. For example, each factor may vary; for example, the surroundings might be uniformed in height, proportion, and design or may differ. The floor may be homogeneous in texture and expansion, or it may have slopes, steps, or different levels, etc. The impression of ceiling height (sky) that is generated by the interplay of the height of the surrounding buildings and the expansion of the wall most of the physical approaches focused on the form of the square, its size, scale, proportion, geographical aspect, and visual complexity (visual and aesthetic elements, from seating, landscaping to subspaces, shelter and protection from sun and cold, lighting, human-scale, etc.).

M. Childs described the basic parts of public squares and their compositional components to help urbanists make better decisions when designing the public square. The first component is the floor of the public square, the horizontal surface enclosed by the walls. It may have consisted of pavements such as driving lanes made of asphalt, brick walkways, and a central pond.

The floor is divided into three parts the catchment area, the frame, and the central field. The catchment space is the area from which most users of the civic room arrive.

The frame is the floor portion that surrounds the central space. It might consist of multiple layers and small fields, subspaces, or civic coves that provide a sense of enclosure and at the same time opened to the large central space, and this is the best space to offer people a chance to sit eat and watch the activities.

The frame is followed by the central field, which is the part of the floor that is compositionally centered in the room. It is an open field that can be a green oasis, water surface, or just paved area, but it may have a statue or any other central figure.

The second component is the enclosing wall: the set of building facades, free-standing walls, arcades, or any vertical planes such as tree lines and fences. This component has a great impact on the space enclosure.

The third component, the virtual ceiling, could be a tree canopy, lights, or any other horizontal plane included in the space settings and control the overhead enclosure.

The composition of these components and each component itself affects the square's sociability. The layout, sub-spaces, placement of elements, the floor levels, green spaces, connectivity, how everything fits together. The physical perspective was the Researchers' first approach when they started to make studies and analysis on public squares to set design criteria. However, with or without intent, urbanists considered human perception while setting recommendations for the public squares in physical perspectives. 


\subsubsection{Perceived design attributes:}

Starting with the enclosure sense, almost all urbanists focus on the public square's enclosure in their observations and studies. They consider the sense of enclosure as an essential principle of the public squares. Camillo Sitte is the first one who considered the sense of enclosure as a principle of the public squares' design after pointing out the safety feeling that enclosure provides. He suggested reducing the number of the surrounding street leads off to the square and decreasing their width or using winding streets to increase the sense of enclosure. According to Cullen, the degree of enclosure affects the visual and physical senses. Alexander et al. analyzed the degree of the enclosure from a different approach. He examined the outdoor space as positive and negative spaces. Accordingly, the way buildings are combined can measure the degree of enclosure. For example, if buildings are close to each other, they can create a well-defined outdoor living room.

Trancik (1986) classified public squares into two types of hard spaces and soft spaces. The hard spaces are well enclosed and well-defined as solid architectural blocks surround them. At the same time, different architectural elements surround soft spaces. French (1978) accepted Alberti and Palladio "s ideas about the relation between the degree of enclosure and the qualities, and dense of the surrounding building elevations, and Ching added buildings patterns of openings, scale, proportion, edges, shape, surface, dimensions, configurations qualities to the interrelations of squares and enclosed buildings. Moughtin (1999) explained that the sense of enclosure could be measured by evaluating the square's gaps in three-dimensional viewpoints and relates the enclosure's degree to the corner and building arrangements as the most accurate expression for the sense of enclosure. Alexander et al. believed that Each element in the public square affects the sense of enclosure vertical and horizontal planes, the arcades, and the trees. Similar to French, when he stated that "Architectural detailing, fencing, walls, trees, shrubbery, awnings, umbrellas and patterns of the ground plane" are another boundary element that provides enclosure to the squares.

Visibility and visuality, when Cullen handled the sense of enclosure with the visual approach. He stated that the enclosure provides a "complete private world that is inwards looking, static and self-sufficient" The sense of in and out appears visually for a person in a square surrounded by buildings. He divided the public square into two spatial qualities.

'hereness' and 'thereness' which are the senses that exist

When the user looks out of the enclosure system.

"Hereness" is the private place close to the user visually, while "thereness" is always far away from the users' perception.

Alexander et al. approached visuality from a different perspective that relates to comfort and seating. He stated that users want to see good views when they are in the public square; however, they do not want to face a blank wall. He suggested public squares to give comfortable viewing feelings to the users.

The inside square viewing is important, but viewing from the square is a significant issue. The viewing from the outside of the square is named by Ching (1979) as 'The approach' the naming was inspired by how the squares are perceived when they are approached. Three main physical 
approach forms exist frontal, oblique, and spiral. When the user approaches the square, the frontal approach when space is seen directly; if space is seen in angular or perspectival view, it is an oblique approach; if the arrival point is hidden and space can be accessed only through a perimeter, it is the spiral approach. The approach is from the outside of the enclosed space, and it is starting with a distant view toward the square and, as a gradual performance, moves to the square entrance where people can see the whole square.

Lynch's studies are based on the environment vision and the city image. Lynch often states that places should be legible or readable. For him, the square's legibility is to increase the visuality of the squares. The physical components should be clear enough, the public squares' objects should be well recognized, and allow citizens to use and experience the squares without wayfinding signs.

Hillier classified public squares' visuality based on squares' layouts. The public squares with axial deformation have more clearly visible spaces, while convex deformation offers wider and narrower visual scenes. He approved that the public square layout can affect the degrees of visibility of the spaces, and the security feeling and usage change density change accordingly.

Bentley et al. relate the users" sensual experiences in public squares to richness quality, and he indicated that the sight is the most important one considering two different scales, the longrange and the close range.

Trancik and Gehl stated that people need good views to attract them to get involved in the square life, and to achieve this, the squares should have attractive elements. These attractive elements could be "water elements, trees, flowers, fine space, good architecture, and artworks."

Not any empty open space in the city can be considered as a square. For the urban space to be accepted as a square, it must have a figure such as a fountain, sculpture, monument, clock tower, and patterned floor. Cullen believed these elements increase the liveliness of the public squares. $\mathrm{He}$ also claimed that these objects, especially the vertical ones, become the city focal points or landmarks which people like to visit and see closely.

When talking about 'landmarks', it must mention that landmarks are one of Lynch's five significant city components. For an object to be a landmark, it needs to be single, unique, catchy, and gain a place in a citizens' memory. Then it becomes a symbolic meaning for the city. But not every monument in a square is Lynch's landmark because not every monument has a dominant character in the city scale.

For Trancik and Cullen, the objects in the public square, such as sculptures, water elements, and trees, offer users many advantages like showing direction, creating focal points, animating the public space, and giving symbolic character square.

Especially when the object is a historical figure, it carries historical and cultural meaning for the society. Lang (2005) mentioned that these objects usage; for example, when users come across a sculpture in the public square, they may pause and spend time sitting on the sculpture's steps, 
which may offer them a different experience. According to Lang (2005), the public squares that do not have any of these elements can be boring.

Whyte's observations prove that while people are waiting, chatting, or standing in the square, they prefer being close to a well-defined object. When he mentioned a well-defined object, He meant objects like flagpoles, statues, or steps. And Alexander et al. gave special interest to the 'steps,' whether they are stepped cafes terraces, steps surrounding public plazas, stepped porches, stepped statues, and seats. Although their main role is to link different levels, people like sitting on the steps and watching public life.

Regarding surfacing and floor patterns, For Trancik, If the environmental structures are compatible with the square's floor patterns, the square is considered well designed, and he mentioned piazza del campo as an example where the radiating pattern of stone strips reinforces the shape of the piazza.

Marcus \& Francis recommended that the hard surface be more than the planted surface in the public square. Because when the planted surface exceeds the hard surfaces, the public square looks like a park rather than a square. At the same time, the planted surface's existence is a must in the public squares to sustain the greenery and planting, which increase the square attractiveness. Additionally, Moughtin stated that the public squares' surfaces should affect space usage. In this regard, the squares with aesthetic elements are more interesting and have a better chance of becoming memorable open spaces for the citizens.

The other aspect discussed in the physical term but has perceptual perspective is the public square size. When discussing the size of the public square, the visual perception must be taken into consideration. The scale and density of the surrounding architectural structures of the square affect the perceived size; for example, the public squares that are surrounded by dense and tall buildings might be perceived as smaller than they are, in fact.

Marcus \& Francis mentioned small squares' success and how users feel they are more convenient than large ones. As long as they are close to pathways, streets, and transportation nodes, people prefer escaping the busy urban and spending their time relaxing and having some quality time. Like many other writers, Moughtin, as well, wrote about the large square negative effects. In his opinion, when the public square has a huge proportion, it turns into an ordinary open space, not a square.

As long as urbanists' investigations clarify that most people prefer being in small squares rather than large squares, the subspaces concept appears as a solution for large squares' designs. The subspaces concept also helps public squares to provide various kinds of activities to attract people. In conclusion, there is a relationship between physical and perceptual design attributes with or without intention since the first design criteria for the public squares. Authors put some recommendations in physical terms, but these recommendations are based on user experience, which means user perception. One perceptual attribute can be achieved by distinguishing multiple physical attributes; for example, a well-defined space can be achieved when architectural blocks surround space, only one or two narrow streets lead off the space, has trees with dense canopies, and its $\mathrm{D} / \mathrm{H}$ ratio is $1: 1$. The physical design attributes are the conclusion of urbanists' observations and investigations, while the perceptual design attributes are the explications of them. 


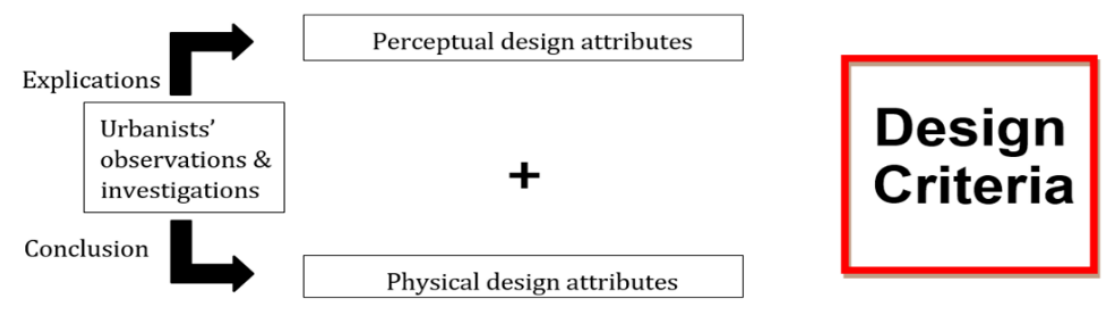

Fig. 1. Shows the relationship between the perceived and perceptual design attributes - source: Basak. Z. (2011), the humanistic meaning of urban square. Pg. 30-100 Adopted by Author.

\subsection{Place-making concept}

"Cities are an immense laboratory of trial and error, failure and success, in city building and city design" J. Jacob,1961.

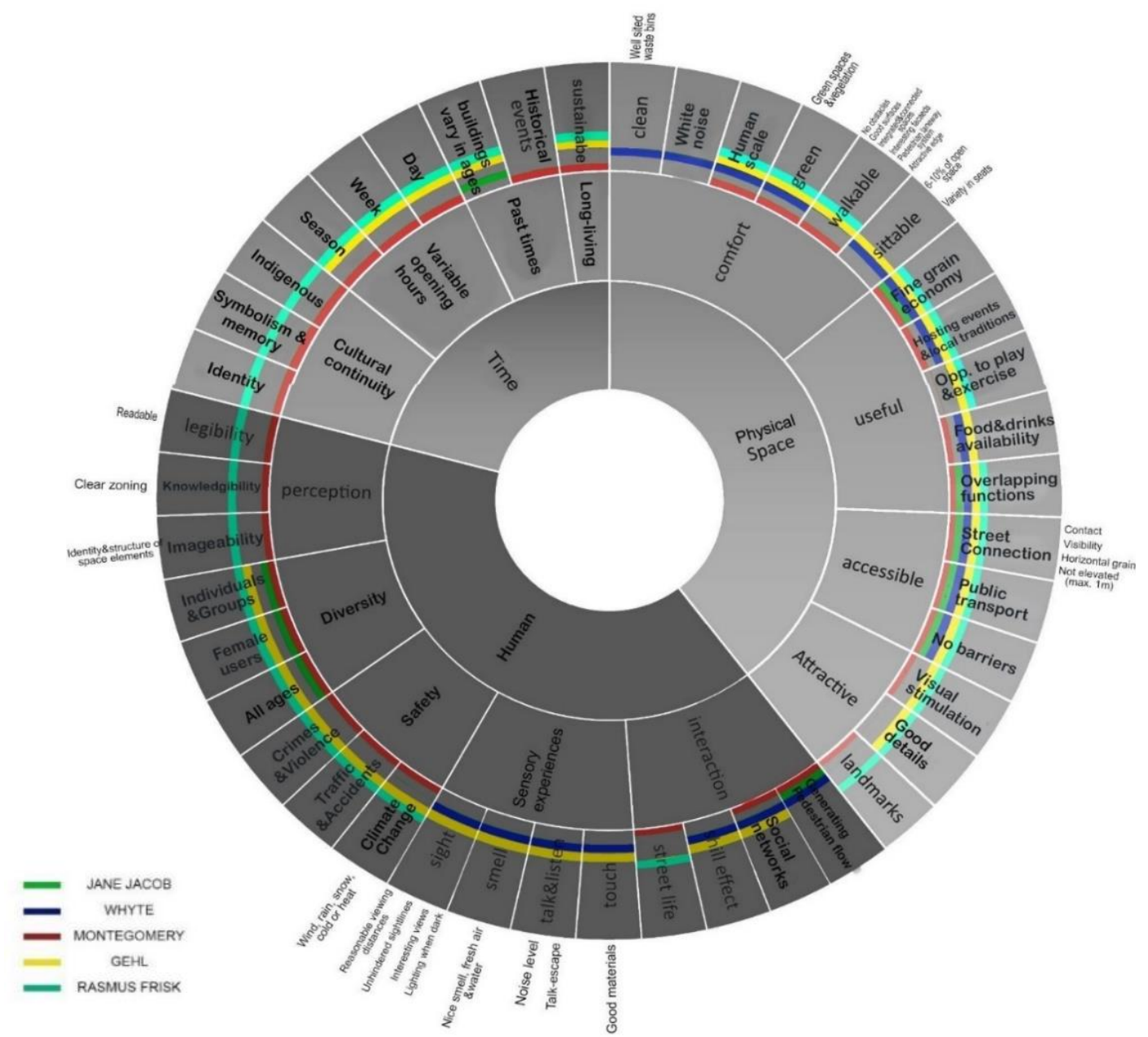

- Fig. 2. Shows the evaluative criteria that has been concluded with color coding that explain which urbanist mention that attribute - source: Montgamery J. (1998), Making a city urbanity, vitality and urban design. Journal of urban design. P.p. 93-100 Adopted by Author. 
Many urbanists, researchers had researched urban public spaces' physical aspects for a long time, and they found a giant and growing range of new developments, but all of them failed to attain user satisfaction. This made them curious to explore different approaches believing that psychological aspects should be considered in addition to the physical dimension of the design process. When considering the two approaches during the design process that can reflect the quality of urban life for users while experiencing the space and make users happy being in this place and want to return. J. Jacob and W. Whyte are the pioneers of that orientation, and they called it "place-making," which is the promotion of urban space quality and concentration on more people-centered cities with lively and inviting public spaces.

Urban design is based on the relationship between time, human, and place, and any urban space such as street, square or park, becomes successful when it offers good quality and urban life experience. It is important to evaluate the user experience in any urban space to enhance the quality of urban life. By comparing diverse opinions of various generations, specific evaluation criteria

have been concluded to evaluate urban spaces' user experience through these three main elements time, human, and the physical space itself.

\section{Examples,}

\subsection{Leicester Square in London, United Kingdom.}

Leicester Square is located in the middle of the West-end, the main commercial and entertainment center in London, England, and the modern west end is closely associated with London's city, the largest central business district in London. A lot of touristic destinations and vital nodes are within walking distance of the square. It is very centered in the north of Trafalgar Square, east of Piccadilly Circus, west of Covent Garden, and south of Circus. Leicester Square was originally entirely residential, then it was known as an entertainment venue, and now it's known as the home of cinema.

Leicester Square has a plentiful history that started in 1635 . Passing by many stages for the squares developments through time in 2010, a huge redevelopment of Leicester Square proposed by Boris Johnson took place as part of a Great Outdoors project, and after 17 months' work at a

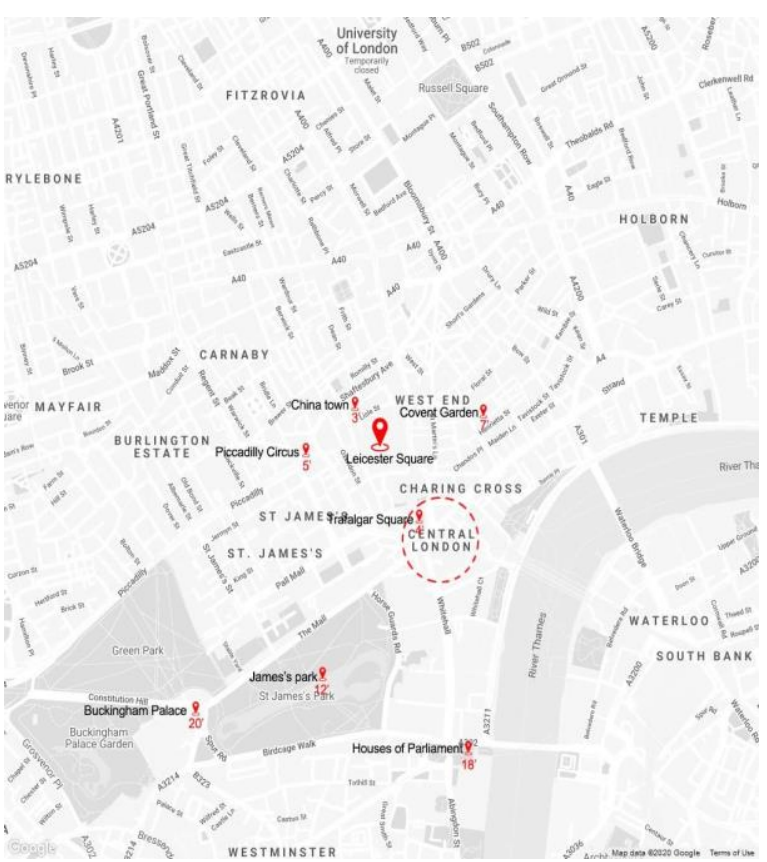

Fig. 3. Shows the Leicester square Location - source: Google. (n.d.-a). [Google Maps nearby to touristic places]. Retrieved March 2021, from https://google.com/maps Adopted by the Author total cost of $£ 15.3$ million, the square re-opened in May 2012 with features of the old and new city combined into one. 


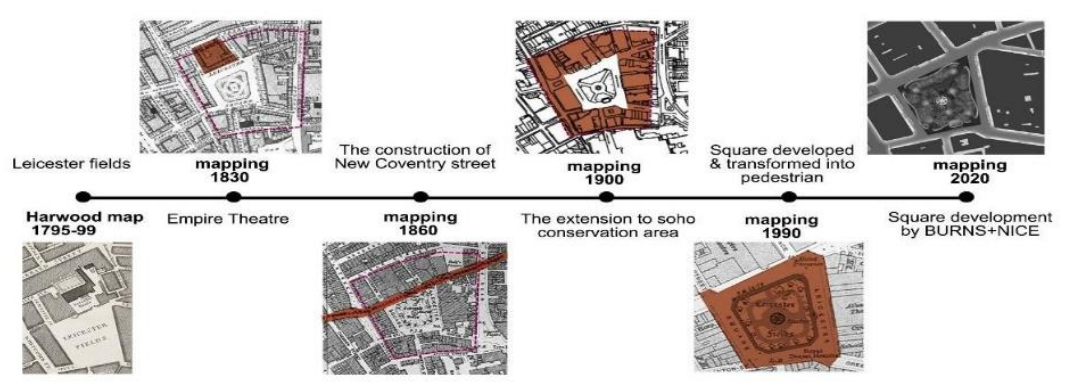

Fig. 4. Shows the Leicester square development history - source: Westminster City Council,2002 Freepost Lon17652 London Sw1e 6yy. adopted by the author

Leicester Square is considered one of the busiest public places all over the world. 250,000 users pass through the Square every day. It has a very active edge or outer square with more than 25 cafés and restaurants, 15 bars and nightclubs, and 7 cinemas. Almost 9,000 people can use the cinemas at any one time plus 12,000 users for the nightclubs. A few come to enjoy the Square itself, and few see the Square as a genuine landmark worthy of a visit and a place to spend time. The result was a transient, unwelcoming atmosphere, which at night can become intimidating and even unsafe. Over seven hundred alcohol-related incidents occur in the West End every year, many of them in and around Leicester Square. It was essential to restore the square value as an entertainment destination as it used to be since 1670 and transform the Square into a welcoming, attractive, clean, and secure landmark at London's heart. SWOT analysis for the square before the transformation is shown in the table below:

Table 1 Shows the Leicester square's SWOT analysis before the transformation - Westminster City Council,2002 Freepost Lon 17652 London Swle 6yy. adopted by the author

\begin{tabular}{|l|l|l|l|}
\hline STRENGTH & $\begin{array}{l}\text { Active edge (outer square). } \\
\text { Central location and nearby many } \\
\text { touristic destinations. } \\
\text { Accessible and walkable. } \\
\text { Pedestraznied }\end{array}$ & OPPORTUNIITY & $\begin{array}{l}\text { Historical square. } \\
\text { Destination. }\end{array}$ \\
& $\begin{array}{l}\text { Good enclosure rate } \\
\text { Suswell known cinemas \& } \\
\text { Surrounded by high value } \\
\text { aesthetic and historical buildings. } \\
\text { Shaded in summer. }\end{array}$ & $\begin{array}{l}\text { Has green oasis and historical } \\
\text { fountain(figure) } \\
\text { Characterized by its strong } \\
\text { business base }\end{array}$ \\
\hline WEAKNESSES & $\begin{array}{l}\text { Seats positioned in corridors with } \\
\text { Aimited views. } \\
\text { Confused spaces. } \\
\text { Enclosed gardens. } \\
\text { Poor quality connections. }\end{array}$ & THREATS hour place \\
\hline
\end{tabular}

The vision of transformation was to build on the Square's positive identity and make it lively for the right reasons, which could be summarized into five points:

\section{Home of cinema,}

As long as the square already had seven cinemas and was hosting some premieres each year. By encouraging premieres and other cinema or creative industry-related events, such as film 
memorabilia festivals and graphic design fairs, and to promote a lively program of themed events, the Square will reflect the modern, imaginative, creative feel of the local area, and people will be encouraged to visit and stay in the Square.

\section{A family atmosphere,}

To emphasize family atmosphere in the square, they made a partnership with the owners of cinemas to show animated films for local children to attract them and they planned to offer children events and dining environment in the square with good deals for public transport and extending family parking it became easier for families to visit and spend more time enjoying the square.

\section{The feel of the square,}

To attract visitors passing across the busy terraces and get an eye-catching view down through the gardens, across the fountain with its statue of Shakespeare, past the collection of lit monuments including the bronze statue of Charlie Chaplin especially in the evening they used public art and lighting schemes which serve to reinforce the atmosphere with a modern theme.

\section{Reinforcing the image,}

It was important to make any new image obvious in the Square itself and in the minds of those who might be visiting London. To that end, they made destination branding for London's heart and the home of entertainment to establish this new, strong image of Leicester Square for potential visitors.

\section{Planning and management,}

It recognized that the improvement of planning and management is not just about planning policies and physical layout, and no doubt, the safety of the square and the activities within the square must be integrated with the vision.

To implement the transformation project vision. It was important to define the transformation project's objectives and how they could be done. The table below summarizes these objectives and the steps to take place to achieve the implementation of these objectives.

Table 2 Shows Leicester square's transformation objectives - source: https://www.westminster.gov.uk/ adopted by the author.

\begin{tabular}{|c|c|c|c|}
\hline Objective 1 & Objective 2 & Objective 3 & Objective 4 \\
\hline Movement & $\begin{array}{l}\text { Functional } \\
\text { mix }\end{array}$ & Historical character & Physical space \\
\hline $\begin{array}{l}\text { *Create more } \\
\text { pedestrian linkage, }\end{array}$ & $\begin{array}{l}\text { *A Welcoming } \\
\text { Environment, }\end{array}$ & $\begin{array}{l}\text { *Integrate early heritage } \\
\text { consideration in design process, }\end{array}$ & *Lighting \\
\hline $\begin{array}{l}\text { Attractiveness } \& \\
\text { security of side streets. }\end{array}$ & & *Respond to existing character, & $\begin{array}{l}\text { Use layered lighting make the } \\
\text { square well and fully lit. }\end{array}$ \\
\hline $\begin{array}{l}\text { *Increase } \\
\text { Walkability, } \\
\text { Encourage people to } \\
\text { walk from one } \\
\text { national landmark to } \\
\text { another. }\end{array}$ & & $\begin{array}{l}\text { *New development needs to be } \\
\text { cooperative and developed within } \\
\text { the frame of the historical } \\
\text { character. }\end{array}$ & $\begin{array}{l}\text { *Gardens, } \\
\text { Making the space welcoming } \\
\text { and integrated by using } \\
\text { blurring edge. } \\
\text { Restoring the fountain. } \\
\text { surfacing, }\end{array}$ \\
\hline
\end{tabular}




\begin{tabular}{|l|l|l|}
\hline & & $\begin{array}{l}\text { High Duty and High Amenity } \\
\text { for the use and function of the } \\
\text { square. }\end{array}$ \\
\hline *Increase \\
$\begin{array}{l}\text { legibility, Way } \\
\text { findings. }\end{array}$ & *Sitting, \\
Democratic seat with view to \\
the square edge.
\end{tabular}

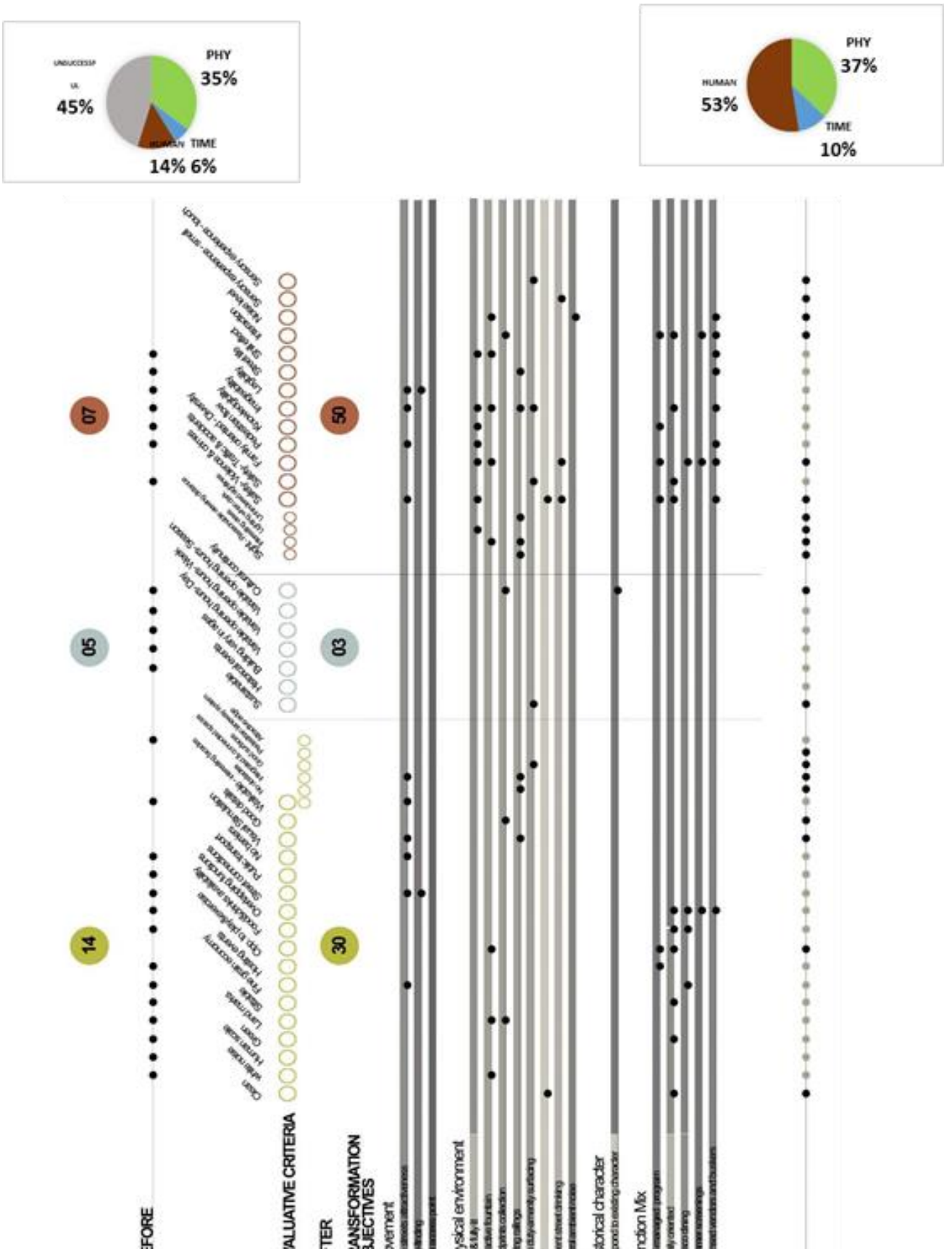

Fig. 5. Shaws the cancluded evaluative criteria applied an Leicester square befare and aft er the trarsfarmatian praject and shaws the

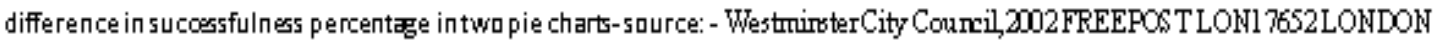
SW1E 6YY. adootedb v the author 
After analyzing the Leicester square transformation and applying assessment criteria on the square before and after the transformation. The following was concluded:

- It wasn't successful enough before, while the physical design attributes were highly considered.

- As long as the square already has a valuable historical background, they did not pay much attention to the related aspect.

- They focused on square safety and how to make it a family-oriented space much more than any other attribute when they considered the perceptual aspect.

\section{Conclusion,}

In conclusion, physical and physiological aspects must be considered in any transformation project as long as the physical aspect is not enough to make a successful square. Having assessment criteria helps evaluate the public square before any transformation proposal is essential to have a clear vision of what exactly causing the lack of the public life experience in the square and how it could be fixed in the new design proposal. Also, that assessment criteria helps to set priorities in the transformation implementation. Public participation is very important before and during the transformation.

\subsection{Recommendations,}

1. Allow public participation before and during the transformation of public square to make sure that the result will fulfill the user satisfaction.

2. Adding cctv system helps in the square safety and cleanness.

3. Let businesses helps in the square maintenance as long as they are taking advantage of the square crowds.

4. Creating program of activities and events to take place the square and the square branding is one of the most factors that attract people to come and return to the square.

\section{References;}

1. Clare Cooper Marcus, Carolyn Francis. (1990) People places: design guide lines for urban open space. New York: Van Nstrand Reinhold, cop, p.p. 27- 29

2. C. Alexander, "A Pattern Language," pp 600, Oxford University Press, New York, 1977. [16] H. Shaftoe, "Convivial Urban Spaces-Creating Effective Public Places," London, Sterling,VA.

3. V. Mehta, "A Toolkit for Performance Measures of Public place," 43rd ISOCARP Congress 2007, Antwerp, Belgium, 19-23 September, 2007.

4. Gehl, J., and L. Gemzoe. 2000. New City Spaces. Copenhagen: The Danish Architectural Press.

5. Krier R. (1979) Urban space. Foreword by Colin Rowe. Great Britain: Academy edition.

6. Lynch, K. (1984). Image of The City. Cambridge, Mass.: MIT Press

7. Miller, K. F., 2007, Designs on the Public: the Private Lives of New Yorkes Public Spaces, University of Minnesota Press, Minneapolis, London.

8. Moughtin, C., 2003, Urban Design: Street And Square, Architectural Press, Amsterdam,Boston.

9. Mumford, E., 2000, The CIAM Discourse on Urbanism: 1928-1960, MIT Press, Cambridge.

10. Montgamery J. (1998), Making a city urbanity, vitality and urban design. Journal of urban design. P.p. 93 100

11. Mozuraityte M. (2012) Visual boundaries in public spaces: Universitat Politècnica de Catalunya, p.p 06-09.

12. Memluk M. (2013), Designing urban squares. Intechopen. P.p. 515-517.

13. Marcus and C. Francis, "People Places: Design Guidelines for Urban Open Space," 2nd 
14. Punter, J., 1991, Participation in the Design of Urban Space, Landscape Design, issue 200: 7-24.

15. Tibbalds, F., 2001, , Making People-friendly Towns, Longman, Essex, (first published in 1992).

16. Şahin, A., 1996, An Analysis of the Attributes of the Square, Master Thesis, Department of City and Regional Planning, METU, Ankara.

17. Sitte, C., 1965, City Planning According to artistic Principles, Columbia University Studies in Art History and Archeology, Random House, New York

18. Talen, E., 1999, Sense of Community and Neighborhood Form: An Assessment of the Social Doctrine of New Urbanism, Urban Studies, 36: 1361-1379.

19. Tunç, G., 2003, Transformation of Public Space: The Case of Migros Akköprü Shopping Center, Master Thesis, Department of Urban Policy Planning and Local Governments, METU, Ankara.

20. Ünver, A., 2009, People"s Experience of Urban Lighting in Public Space, Master Thesis, Department of City and Regional Planning, METU, Ankara.

21. Westminister's city plan from: http:// https://www.westminster.gov.uk/

22. W. H. Whyte, "The Social Life of Small Urban Spaces," Washington, D.C., 1980.

23. Whyte, W., 2009, City: Rediscovering the Center, University of Pennsylvania Press, Philadelphia, (first published in 1988).

24. Zafarullah M. (2017) PHYSICAL CHARACTERISTICS OF A PUBLIC SQUARE IN MALAY

ROYAL TOWN, Journal of Digital Landscape Architecture, P.p. 01-03 
N. Mazroua, An Evaluative Approach for the Development of Historical Public Squares ; Vol. 9, R. 2021, Issue No. 2.

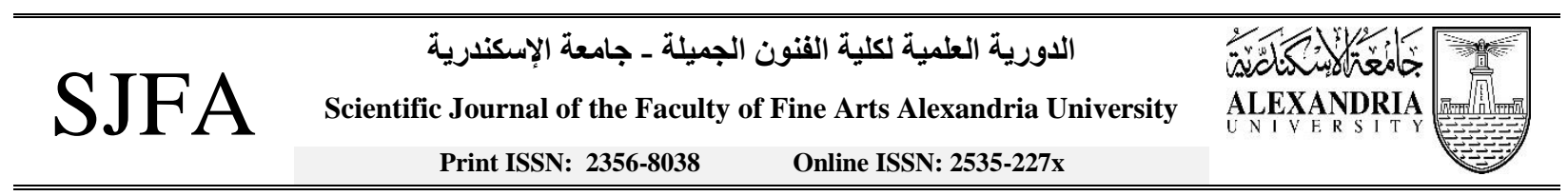

\section{نهج لتقييم تطوير الميادين العامة التاريخية}

نور مزروعة

الملخص

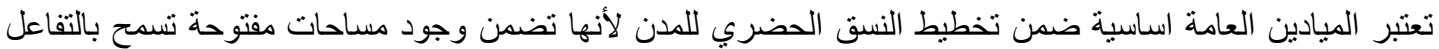

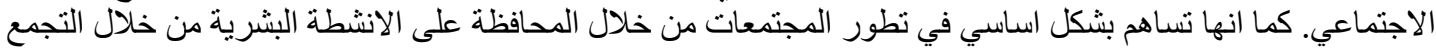

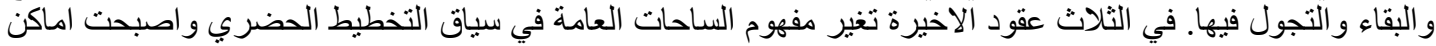

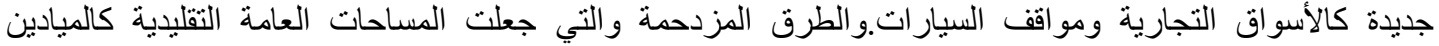

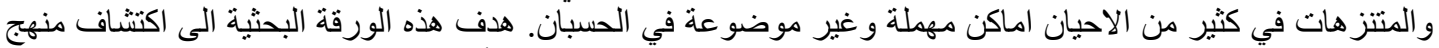

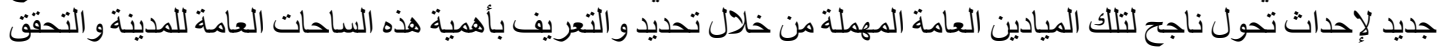

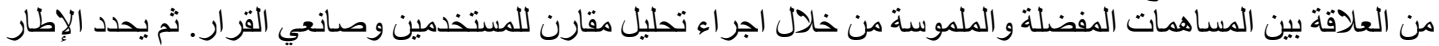

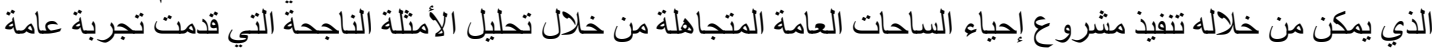
مميزة. الكمات الدالة: تنشيط الساحات العامة ، الحيزات الحضرية ، الساحات المهلة ، الخبرة العامة.. 